\title{
The Effect of Listening Attitude and Listening Anxiety on Listening Comprehension: A Regression Model
}

\author{
Esra Karakuș Tayşi \\ Department of Turkish and Social Sciences Education, Faculty of Education, Kütahya Dumlupınar University, Turkey
}

Copyright $\subseteq 2019$ by authors, all rights reserved. Authors agree that this article remains permanently open access under the terms of the Creative Commons Attribution License 4.0 International License

\begin{abstract}
Since listening is a multi-dimensional skill that involves many factors, it is very difficult to identify variables that affect the process. In the current study, it is aimed to determine whether anxiety and attitude are thought to be among the factors affecting listening affect listening comprehension process. To this end, the study employed the relational research method. The study was conducted on 187 seventh grade students attending a state middle school in the city of Kütahya in 2017- 2018 academic year. The results obtained have revealed that there is a significant and negative correlation between the students' listening comprehension and anxiety and a significant and positive correlation between their listening comprehension and listening attitude. Moreover, a significant, medium and positive correlation was found between their listening anxiety and listening attitude, and listening comprehension. It was also found that $29 \%$ of the variance in the depending variable, listening comprehension, is explained by two independent variables, listening anxiety and listening attitude.
\end{abstract}

Keywords Listening Anxiety, Listening Attitude, Listening Comprehension

\section{Introduction}

One of the first skills acquired by the individual and providing the basis for most learning is the skill of making sense of the heard sounds. Gögüş [1] defines the listening as a spiritual event, distinct from hearing and as a process requiring paying attention to understand what is heard and following speech to draw a conclusion.

Occurrence of listening depends on healthy sense of hearing. Being a physiological event, hearing means receiving sounds coming from external sources; accordingly, a pre-requisite for listening to occur because listening refers to construction of the heard sounds in the mind in such a way as to make sense of them. The physical and mental processes of the individual need to be developed in order for a thorough listening to occur [2].
Rost [3] states that there are four dimensions of the task of listening which are receptive, constructive, collaborative and transformative. He defines the act of listening on the basis of these dimensions. While he defines the receptive dimension as "Listening is decoding the message received from the speaker, uncovering the content relayed by the speaker, understanding what is in the mind of the speaker and the reflection of the speaker's beliefs, attitudes and emotions". He also defines the constructive dimension as "Listening is finding out what is in the mind of the speaker, recognizing the meaning of what is not said and renaming the message of the speaker in such a way as to make it more suitable for the listener". He defines the collaborative dimension as "Listening is responding to what is said by the speaker, acquisition, processing and storing of information in an interpersonal context." And he finally defines the transformative dimension as "Listening is a process of creating meaning in the speaker and changing the cognitive environment of both the speaker and listener."

Hrisch [4], on the basis of the definition of listening made by researchers, states that there are at least ten different conceptual components of listening. These include hearing, interpreting, understanding, making sense, influencing sound stimuli, selectively receiving sound stimuli, remembering, consciously participating in sound stimuli, analyzing the presented information, and using past experiences as a filter of transmitted information. With all these dimensions involved, he states that listening is a complex activity that should not be attempted to be shown as simple.

When the definitions of listening are examined, it is seen that an effective listening is something more than a cognitive process, because the listener should understand not only what is being said, but also non-verbal messages. Rost [3] says that listening is an invisible process that requires indirect explanations and that cannot be observed directly. Therefore, the development of listening skills is highly difficult because there are many factors that affect the process and are difficult to define. According to Çifçi [5], many factors such as the nature of the message 
received, the visual behavior of the message source, how the communication medium is used, the purpose for which the listener listens, and many other psychological and social factors affect listening. Due to these factors, the listening ability of the individual may not be improved and the failures experienced may cause anxiety.

\subsection{Listening Anxiety}

Anxiety is a feeling that can be experienced in any part and situation of one's life. Köseler [6] sees anxiety as a persistent, distressing psychological situation that emerges from the internal conflicts of the individual. Spielberger [7] defines it as "emotional reactions including tension sensation, fear and irritability, unpleasant thoughts (concerns) and physiological changes"; Budak [8] defines anxiety as a reaction triggered with the influence of forces oppressed in the mind against a factor that has not been perceived yet.

The anxiety that affects human activities also affects learning significantly. Although the relationship between anxiety and learning is thought to be negative, it is not always negative. Sometimes moderate level of anxiety can lead to the highest efficiency [9]. Learning does not only involve a cognitive dimension but also an affective dimension and anxiety affects this affective dimension. Scarcella and Oxford [10] categorized anxiety into two as debilitating and facilitating anxiety depending on the effect it induces. Facilitating anxiety is stated to be facilitating the learning process by enabling students to attach greater importance to the subject and debilitating anxiety is stated to be negatively affecting student performance by decreasing the participation in the process and distancing students from the activity of listening.

Affective states have positive or negative effects on the development of language skills. One of these affective states, anxiety can significantly affect the listening skill having dominant mental and psychological dimensions. Listening anxiety can be defined as the listener's feeling worried, panicked, afraid and frustrated as a result of not making sense of what has been listened during the listening process. Melanlıoğlu [11] suggests that listening anxiety should be evaluated at three stages; before listening, while listening and after listening. He also states that in the before listening stage, distracted attention and lack of knowledge about the material to be listened will prevent the process from occurring smoothly and in the after listening stage, if the newly learned information cannot be associated with the prior knowledge, then the anxiety level will increase. This state of anxiety particularly emerging in situations where listening is compulsory such as in-class listening or exam adversely affects the individual's listening process. Scarcella and Oxford [10] also argue that listening anxiety is felt when students encounter a very challenging or unfamiliar task.

Activities conducted in oppressive classroom environments, where the teacher asks students to participate in the listening activity without making any noise, make the listening process ineffective and cause anxiety to increase so that students develop negative attitudes towards listening [12]. Moreover, the idea of being evaluated at the end of the process makes students concerned.

In the literature, there are many studies showing that the state of anxiety has some effects on writing skill [13-15], speaking skill [16-19], reading skill [20,21]. In these studies, it was found out that with increasing level of anxiety, the level of success decreases. Horwitz, Horwitz and Cope [22] also stated that there is a significant correlation between anxiety and language skills and that the anxiety-inducing psychological characteristics are influential on speaking and listening. Given the psychological dimensions of listening, it can be argued that the individual can develop positive attitudes towards listening if the effect of anxiety on the listening process is minimized, leading to increasing listening comprehension.

\subsection{Listening Attitude}

Attitude, which means "being ready" in Latin [23], is a mental, emotional and behavioral predisposition organized by the individual on the basis of his/her experiences, knowledge, emotions and motives in relation to any other object, social issue or event [24]. The attitude, which refers to a tendency to react rather than a form of response, has been one of the basic subjects of social psychology, as it affects both social perception and behavior [25]. Attitudes are not innate; they are learned through the individual's experiences during the process of socialization and persist for a certain period of time. They may lead to positive or negative behaviors [26,27].

Attitudes are made up of three sets of components. These are affective components including feelings towards an attitude object; behavioral components including observable behaviors; cognitive components including opinions and beliefs. In this connection, though the attitude can be seen as a complex construct, its components make it a system having an internal consistency in itself. In this way, the individual's feelings towards various objects, events etc., his/her opinions, knowledge about them and behaviors developed towards them show consistency and persistency [26]. Considering that attitudes are one of the factors driving behaviors, the importance of the educational-instructional process in the formation and development of attitudes cannot be ignored. According to Açıgöz [28], one of the variables affecting the success in education is the student's attitudes towards some elements such as subject, school, teacher and so on; thus, if the student has positive attitudes towards education, his/her success will increase.

Considering that listening is the most frequently used skill in both educational life and social life, individuals' 
having positive or negative attitudes towards listening will affect their success in many areas. According to Goh and Taib [29], students can easily be passive during the listening process, which causes them to be bored with and reluctant for listening. Therefore, students' developing positive attitude towards listening is very important in terms of the development of listening skill.

In many study, it has been concluded that when the listening process is planned taking students' personal characteristics and interests into consideration, the listening comprehension achievement increases and attitudes towards listening develop in a positive direction [2,30-32]. Because listening is a multi-dimensional skill that involves many factors, it is very difficult to identify variables that affect the process. In the current study, it is aimed to determine whether anxiety and attitudes that are thought to be two of the factors affecting listening have an effect on the listening comprehension process.

When the literature is reviewed, it is seen that while there are many studies exploring the relationship between listening anxiety in foreign language learning and listening comprehension [33-38], there is a paucity of research investigating listening anxiety in mother tongue $[39,40]$; attitude $[2,30,32,41]$; and listening anxiety and attitude together $[31,42]$. No study investigating the relationship between listening anxiety, attitude and listening comprehension has been encountered. In this respect, it is needed to determine the effect of listening anxiety and attitude on listening comprehension.

\section{Materials and Methods}

The current study employed the relational research method. This method is used to explain the relationships between variables, to determine whether these variables affect each other and to predict the results. By means of statistical tests, it is attempted to determine the level of the correlation between two or more variables. During the process, instead of attempts made to affect or control the variables as is the case in experimental studies, statistical comparisons for each sample are included. Correlation test used to identify the level of the correlation reveals whether two or more variables demonstrate consistent changes in relation to one another. If there is a consistent change, then it can be argued that the variables have a common variance or change in tandem [43].

\subsection{Study Group}

The current study employed the relational research method. This method is used to explain the relationships between variables, to determine whether these variables affect each other and to predict the results. By means of statistical tests, it is attempted to determine the level of the correlation between two or more variables. During the process, instead of attempts made to affect or control the variables as is the case in experimental studies, statistical comparisons for each sample are included. Correlation test used to identify the level of the correlation reveals whether two or more variables demonstrate consistent changes in relation to one another. If there is a consistent change, then it can be argued that the variables have a common variance or change in tandem [43].

\subsection{Data Collection Tools}

As the data collection tools in the current study, "The Listening Anxiety Scale for Middle School Students", "The Listening Attitude Scale for Middle School Students" and "The Listening Comprehension Achievement Test" were used.

\subsubsection{The Listening Anxiety Scale for Middle School Students}

It was developed by Melanlıoğlu [11]. It is a 37-item five-point Likert scale having five factors. Cronbach Alpha reliability coefficient calculated for the internal reliability of the scale is 0.927 . In the current study, the reliability of the scale was re-tested and Cronbach Alpha coefficient was calculated to be 0.89 .

\subsubsection{The Listening Attitude Scale for Middle School Students}

It was developed by Karakuş Tayşi [2]. It is a 30 -item five-point Likert scale having four sub-dimensions. Cronbach Alpha reliability coefficient calculated for the scale is 0.824. In the current study, Cronbach Alpha reliability coefficient was calculated to be 0.78 .

\subsubsection{Listening Comprehension Achievement Test}

It was developed by Karakuş Tayşi [2] and it consists of 12 questions. Its KR-20 reliability coefficient is .80 . According to Özdamar [44] if Cronbach Alpha coefficient is between 0.80 and 1.00 , then the reliability of the scale is high. Thus, the scales used in the current study are reliable.

The data of the study were collected by administering the scale at different time intervals.

\subsection{Data Analysis}

Correlation analysis was run to determine the correlations between listening comprehension, listening anxiety and listening attitude; multiple regression analysis was performed to determine the extent to which listening anxiety and listening attitude predict listening comprehension. In the analysis of the collected data, SPSS 21 program package was used.

\section{Findings}

Pearson correlation coefficient was calculated for the 
variables of listening comprehension, listening anxiety and listening attitude to determine the correlation between these variables and the results are given in Table 1.

Table 1. Results of the Correlation Analysis Conducted to Determine the Correlation between Listening Comprehension, Listening Anxiety and Listening Attitude

\begin{tabular}{|c|c|c|c|}
\hline & $\begin{array}{c}\text { Listening } \\
\text { Comprehension }\end{array}$ & $\begin{array}{c}\text { Listening } \\
\text { Anxiety }\end{array}$ & $\begin{array}{c}\text { Listening } \\
\text { Attitude }\end{array}$ \\
\hline $\begin{array}{c}\text { Listening } \\
\text { Comprehension }\end{array}$ & 1.000 & 1.000 & \\
\hline $\begin{array}{c}\text { Listening } \\
\text { Anxiety }\end{array}$ & $-.485^{* * *}$ & $-.188 * * *$ & 1.000 \\
\hline $\begin{array}{c}\text { Listening } \\
\text { Attitude }\end{array}$ & $.313 * * * *$ & $-13 * 00$ \\
\hline
\end{tabular}

$* * *: \mathrm{p}<.01$

As can be seen in Table 1, there is a negative and significant correlation between the students' listening comprehension and listening anxiety $(\mathrm{r}=-0.485, \mathrm{p}<.001)$. The correlation between listening comprehension and listening attitude was found to be positive and significant $(\mathrm{r}=.313, \mathrm{p}<.001)$.

The findings related to whether the regression assumptions are satisfied before testing the regression model are as follows:

First, the correlation coefficients between the independent variables were examined to determine whether there is multicollinearity and it was found that the correlation between the variables is not higher than .80 . Moreover, the highest value of condition Index-CI was found to be 24.732. If CI value is 30 or bigger, it can be said that there is multicollinearity problem [45]. According to this result, it can be said that multicollinearity assumption is not violated.

When the data showing whether there is collinearity between the variables are examined, it is seen that tolerance value of both variables is higher than 0.1 and VIF value is lower than 10 . These findings also show that there is no collinearity problem [45].

When the graph related normality of the error variance (Figure 1) is examined, it is seen that it is in the bell-shaped curve. Thus, it can be said that errors have a normal distribution. The assumption that errors should have constant variance for each observation was also checked with the scatter diagram. When the scatter diagram is examined, it is seen that it does not have a certain shape. That is, the variance of errors is not related to the predicted values. In light of all these findings, it can be argued that multiple regression assumptions were not violated. As a result, it can be said that the regression model obtained in relation to the prediction of the listening comprehension skill is significant and valid.

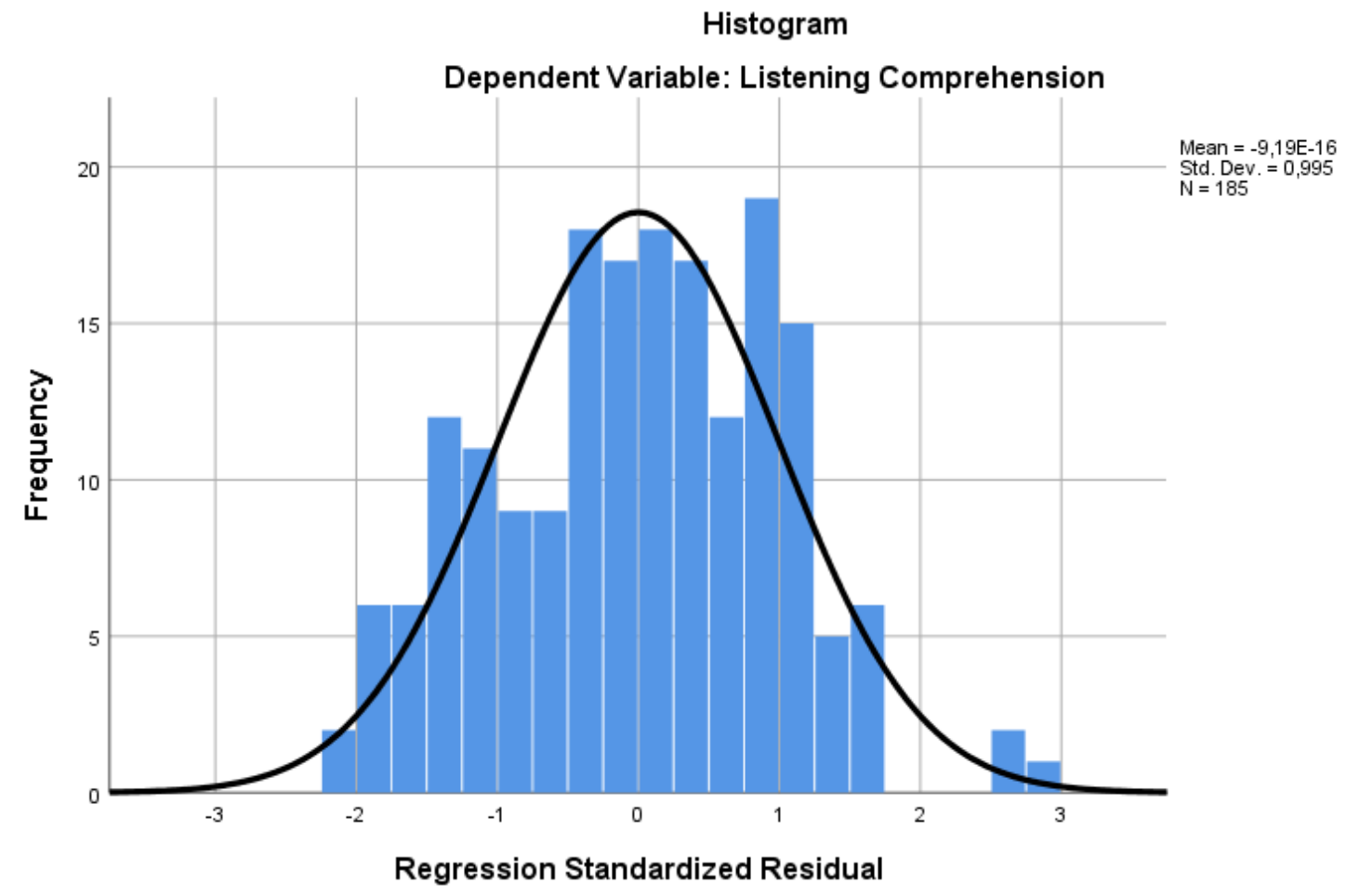

Figure 1. Regression Error Variance 


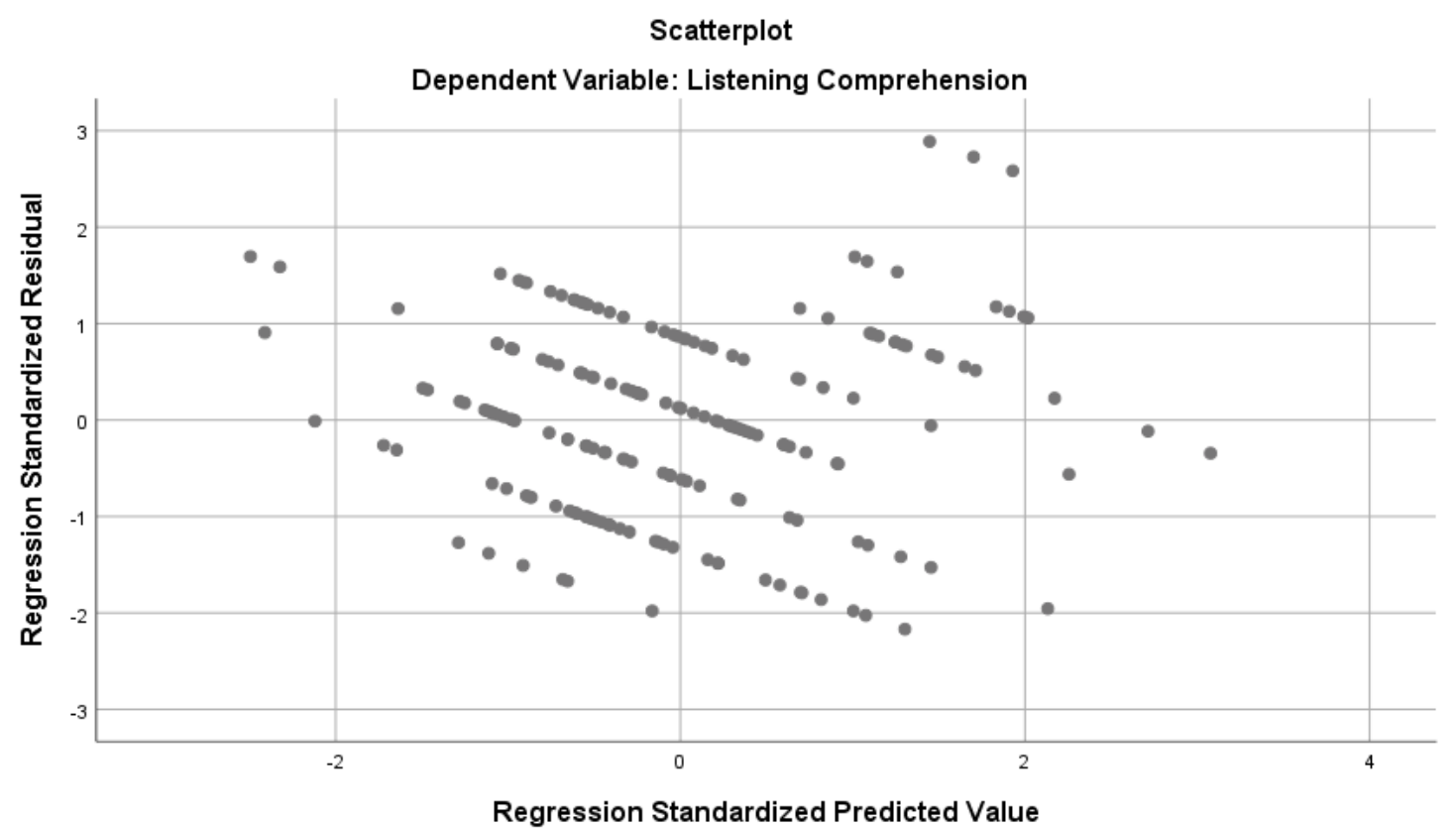

Figure 2. Scatter Diagram for Standardized Predicted Listening Comprehension and Regression Residuals

Table 2. The Results of Multiple Regression Analysis Conducted to Determine Whether Listening Anxiety and Listening Attitude Predict Listening Comprehension

\begin{tabular}{|c|c|c|c|c|c|c|c|c|}
\hline Variables & $\mathrm{B}$ & Standard Error & $\beta$ & $\mathrm{t}$ & $\mathrm{p}$ & Partial r & Tolerance & VIF \\
\hline Constant & 5.112 & 1.13 & & 4.53 & .000 & & & \\
\hline Listening Anxiety & -.034 & .005 & -.442 & -6.94 & .000 & -.457 & .965 & 1.037 \\
\hline Listening Attitude & .031 & .009 & .230 & 3.61 & .000 & .258 & .965 & 1.037 \\
\hline
\end{tabular}

When the results of the multiple regression analysis conducted to determine whether listening anxiety and listening attitude predict listening comprehension in Table 2 are examined, it is seen that there is a positive, medium and significant correlation between listening anxiety and listening attitude and listening comprehension $(\mathrm{R}=.535$; $\mathrm{R} 2=.286 ; \mathrm{p}<.001)$. The coefficient of determination of the tested multiple regression model was found to be $\mathrm{R} 2=.286$. This finding shows that nearly $29 \%$ of listening comprehension, which is the dependent variable, can be explained by the independent variables in the model. Moreover, as an indicator of the determination of the model, the corrected R2 value was found to be 0.279 . The corrected value seems to be quite close to R2. The standard error of the predictions was calculated to be 1.36003 .

According to the results of ANOVA-F statistics testing the significance of the model $(\mathrm{F}=36.536 ; \mathrm{sd} 1=2 ; \mathrm{sd} 2=182$; $\mathrm{p}<.001$ ), it can be argued that the regression model is significant as a whole. According to the standardized regression coefficient $(\beta)$, the predictor variables can be put into order of importance in terms of their influence on listening comprehension as follows; listening anxiety and listening attitude. When the results of $t$ test related significance of regression coefficients are examined, it is seen that listening attitude and listening anxiety are significant predictors of listening comprehension. According to the results of regression analysis, the regression equation (mathematical model) regarding the prediction of listening comprehension is as follows;

Listening Comprehension $=5.112+(-.034 *$ Listening Anxiety $)+(.031 *$ Listening Attitude $)$

\section{Results and Discussion}

In the current study, first the correlations between listening comprehension and listening anxiety and listening attitude were investigated. The results of the analyses have revealed that there is a significant and negative correlation between listening comprehension and listening anxiety and that there is a significant and positive correlation between listening comprehension and listening attitude. This may indicate that with decreasing listening anxiety, middle school students' listening comprehension achievement increases while with improving listening attitude, their listening comprehension achievement also increases.

Tough there is no study directly investigating the 
relationship between listening comprehension and listening anxiety within the context of teaching Turkish as a mother tongue, there are few studies looking at the effects of different variables. Melanlıoğlu [39] gave listening instruction to middle school 8th graders by using authentic materials and found that the students' high level of listening anxiety before the instruction decreased after the completion of the instruction. Arslan [40] conducted a study to determine the middle school students' listening anxiety and academic self-efficacy and their relationships with different variables and found that the students' listening anxiety and self-efficacy vary significantly depending on the variables and the correlation between them is medium and negative. Uçgun [46] looked into the relationship between the middle school students' reading and listening anxiety and found a significant, medium and positive correlation. According to Melanlığlu [11], when students encounter a challenging or unfamiliar task of listening, they feel anxious and when they cannot recognize the words they have listened or misunderstand what they have listened or make wrong inferences, their anxiety increases more. In this respect, there is a great responsibility to be assumed by teachers. Teachers first should create democratic classroom environments where students won't feel hesitant to express themselves because in a tense classroom environment, anxiety increases. In addition to this, students should be encouraged to participate more actively in the process by bringing variety to listening tasks.

The relationship between listening comprehension and listening anxiety has been a subject of more research within the context of foreign language teaching. In a study conducted by Zhai [47], on freshman students learning English, findings similar to the ones of the current study were reported. He found a significantly negative correlation between the students' listening anxiety and listening comprehension. Golchi [48], carried out a study on the Iranian IELTS students and reported that listening anxiety is negatively correlated with listening comprehension and the use of listening strategies. It was also found that the students with low level of anxiety performed better in the listening comprehension test. Halat and Özbay [49], conducted a study with learners of Turkish as a foreign language and found that the participants have a medium level anxiety and the variables such as gender, education level do not have significant influences on the level of anxiety. In their study supported with interviews, they found that initial anxiety level of the students was high; yet, as their skills developed, their high level of anxiety was reduced to medium level of anxiety. Otair and Abd Aziz [50], performed a case study on two students learning English and concluded that the participants experienced high level of anxiety while engaged in listening comprehension tasks. Working with EFL students, Bayat, Jamshidipour and Hashemi [51], investigated the effect of formative assessment on the students' listening comprehension and anxiety level. They stated that before the application, the students' listening comprehension was low and listening anxiety was high; yet, after the application, while their listening anxiety decreased, their listening comprehension improved. These findings concur with the findings of the current study and show that if students are allowed to engage in suitable activities and are given feedbacks, their level of anxiety decreases while their listening comprehension improves. Vogely [52], also remarked that one of the most notable factors decreasing listening comprehension is anxiety; yet, anxiety is overlooked to a great extent during the listening process. Yang [53] explored the relationship between language learning anxiety and listening achievement and concluded that alleviation of anxiety is significantly and positively correlated with listening achievement; yet, very low level of anxiety is negatively correlated with listening achievement. This finding supports the argument that medium level of anxiety positively affects achievement.

The number of studies focusing on listening comprehension and attitude is also very small. This might be because of the dominant belief that listening is not a skill that needs to be worked on and the fact that listening is a skill affected by many factors and difficult to measure. Christenberry [54] emphasized the problematic nature of listening and that it is very difficult to give a regular instruction on it and thus it causes anxiety.

Kılınç [41] offered listening classes to the elementary school students organized on the basis of active learning techniques and while prior to the application, the students' listening comprehension achievement was low and their attitudes towards listening were negative, their achievement increased and their attitudes became more positive after the application. Karakuş Tayşi [2] determined the learning styles of the middle school students and planned the listening classes taking these styles into consideration. After the application, the students' achievement increased and their listening attitudes became more positive. Katranc1 [30] also reported similar findings. These findings also concur with the findings of the current study. With increasing listening comprehension achievement, attitudes towards listening also change in the positive direction. In the international literature, listening attitudes have been researched more in the fields such as psychology and public relations rather than in education. The studies conducted within the field of education on the other hand mostly investigated the attitudes developed by local students towards foreign students.

Another finding of the current study is that listening anxiety and listening attitude are significant predictors of listening comprehension. A significant, medium and positive correlation was found between listening anxiety and listening attitude and listening comprehension. It was also found that $29 \%$ of the variance in the depending variable, listening comprehension, is explained by two 
independent variables, listening anxiety and listening attitude.

No study investigating the effect of listening anxiety and listening attitude on Turkish children's listening comprehension has been detected. Daşöz [31] and Harmankaya [42] carried out a study to explore students' listening attitude and anxiety; yet, they performed an experimental application and investigated its effect on listening comprehension, listening attitude and anxiety. In a study by Daşöz [31], it was found that structured listening activities improved listening comprehension achievement yet did not affect listening anxiety. Harmankaya [42] gave metacognitive strategies training to middle school students and found that it did not lead to a significant difference in the students' listening anxiety and listening attitudes. This makes us think that anxiety levels and attitudes cannot be changed with short-term interventions and long-term and more comprehensive training needs to be conducted to improve students' listening comprehension skills. MacIntyre and Gardner [55] stated that with people's improving listening skill, their self-confidence increases and accordingly their anxiety decreases and they exhibit more positive attitudes towards new listening tasks.

Given that listening is one of the first skills acquired by the individual and provides basis for most learning, it is clear that great importance should be attached to developing this skill from early ages. Funk and Funk [56] argue that most of the students at school are poor listeners and teachers do not know how to help these students improve their listening skills. They also emphasize that many teachers believe that listening can naturally develop. For students to be successful in listening, first teacher must admit that listening is a skill because according to Hyslop and Tone [57] listening provides the basis for the linguistic and cognitive development. Listening also plays an important role in learning and communication processes necessary for an effective participation in life. Two of the factors affecting this process are anxiety and attitudes; therefore, factors causing anxiety and negative attitudes should be researched and a systematic training should be organized to find solutions.

\section{REFERENCES}

[1] Göğüş, B. Orta dereceli okullarımızda Türkçe ve yazın eğitimi. Gül Yayınevi: Ankara, 1978.

[2] Karakuş Tayşi, E. The effect of learning styles-based instruction on secondary school students' listening comprehension skills and their attitudes to listening. (Unpublished doctoral dissertation). Gazi University, Ankara, Turkey, 2014.

[3] Rost, M. Teaching and Researching Listening. Published by Routledge, New York, 2011.
[4] Hirsch, R. On defining listening: synthesis and discussion. https://www.researchgate.net/publication/234630434_On Defining_Listening_Synthesis_and_Discussion [accessed Nov 01 2018].

[5] Çifçi, M. Dinleme eğitimi ve dinlemeyi etkileyen faktörler. Afyon Kocatepe Üniversitesi Sosyal Bilimler Dergisi, 2 (2). 2001.

[6] Köseler, A. Communication anxiety among the high school students (Unpublished master's thesis) Çanakkale on Sekiz Mart University, Çanakkale, Turkey, 2006.

[7] Horwitz, E. Language anxiety and achievement. Annual Review of Applied Linguistics, 21, 112-126, 2001. From Spielberg.

[8] Budak, S. Psikoloji sözlüğü. Ankara: Bilim ve Sanat Yayınları, 2017

[9] Cüceloğlu, D. İnsan ve davranıșı-psikolojinin temel kavramları. İstanbul: Remzi Kitabevi, 2012.

[10] Scarcella, R. and Oxford, R. The Tapestry of Language Learning: The Individual in the Communicative Classroom. Heinle \& Heinle, Boston, MA, 1992

[11] Melanlıoğlu, D. Reliability and validity of the listening anxiety scale for secondary school students. Adiyaman Üniversitesi Sosyal Bilimler Enstitüsü Dergisi Türkçenin Eğitimi Öğretimi Özel Sayısı, 6 (11), 851-876, 2013, From Tobias.

[12] Umagan, S. Dinleme.(Ed.A. Kırkkılıç, H. Akyol). İlköğretimde Türkçe Öğretimi. Ankara: PegemA Yayıncılık, 2007.

[13] Bayat, N. The Effect of the Process Writing Approach on Writing Success and Anxiety. Educational Sciences: Theory \& Practice, 14(3), 1133-1141, 2014.

[14] Karakaya, İ.; Ülper, H. Developing a writing anxiety scale and examining writing anxiety based on various variables. Kuram ve Uygulamada Eğitim Bilimleri, 11(2), 691-707, 2011.

[15] Karakuş Tayşi, E.; Taşkın, Y. Development of the writing anxiety scale for secondary school students: reliability and validity study. Uluslararası Türkçe Edebiyat Kültür Eğitim Dergisi, 7(2), 1172-1189, 2018.

[16] Demir, T., Melanlığlu, D. Speaking anxiety scale for secondary school education students: validity and reliability study. Ankara University, Journal of Faculty of Educational Sciences, 47 (1), 103-124, 2014.

[17] Katranc1, M., Kuşdemir, Y. Investigation of speaking anxiety of pre-service teachers: an application for speaking course Dicle Üniversitesi Ziya Gökalp Eğitim Fakültesi Dergisi, 24, p. 415-445, 2015.

[18] Sevim, O. Speaking anxiety scale for prospective teachers: a validity and reliability study. Turkish Studies - International Periodical for the Languages, 7(2), 927-937, 2012.

[19] Kavruk, H., Deniz, E. Speaking anxiety of secondary school students (Samsun province example). Dil ve Edebiyat Eğitimi Dergisi, 2015.

[20] Melanlığlu, D. Impact of metacognitive strategies instruction on secondary school students' reading anxieties. 
Eğitim ve Bilim, 39(176), 107-119, 2014.

[21] Ürün Karahan, B. Examination of the relationship between reading anxiety and self-efficacy perception for reading comprehension in 5th grade students. European Journal of Education Studies, 4 (9), 98-107, 2018. doi: 10.5281/zenodo. 1294294 .

[22] Horwitz, E. K., Horwitz, M. B. ve Cope, J. Foreign language classroom anxiety. Modern Language Journal. 70 (2), 125-132, 1986.

[23] Arkonaç, S.A. Sosyal psikoloji. Değiştirilmiş ve Genişıletilmiş 2. Baskı, İstanbul: Alfa Basım Yayım Dağıtım, 2001.

[24] İnceoğlu, M. Tutum, algı, iletişim. Ankara: Elips Kitap, 2004.

[25] Kağıtçıbaşı, Ç. Günümüzde insan ve insanlar (12. Bask1). İstanbul: Sistem Matbaacılık, 2010

[26] Tavşancıl, E. Tutumların ölçülmesi ve SPSS ile veri analizi (4.Baskı). Ankara: Nobel Yayınları, 2010.

[27] Hogg, M.A., Vaughan, G.M. Sosyal psikoloji (Çev.İbrahim Yıldız, Aydın Gelmez) (2.Baskı). Ankara: Ütopya Yayınevi, 2011.

[28] Açıkgöz, K.Ü. İş birlikçi öğrenme kuram araştirma uygulama. Malatya: Uğurel Matbaası, 1992.

[29] Goh, C.; Taib, Y. Metacognitive instruction in listening for young learners. ELT Journal, 60(3), 222-232, 2006

[30] Katranc1, M. Effects of teaching metacognition strategies to listening comprehension skills and attitude toward listening, Unpublished doctoral dissertation, Hacettepe Üniversitesi Sosyal Bilimler Enstitüsü İlköğretim Ana Bilim Dalı, Ankara, Turkey, 2012.

[31] Daşöz, T. 2013; An Investigation of the effect of constructed listening activities on seventh grade students' listening attitudes, listening anxiety and level of listening comprehension. (Unpublished master's thesis), Niğde University, 2013.

[32] Sis, N.; Başpınar Yörük, N. Effect of musical creative listening activities on the listening success and attitudes of the seventh grade students. International Journal of Language Academy, 5(7), 1-16, 2017.

[33] Rezaabadi, O. T. The relationships between social class, listening Test anxiety and test scores. Advances in Language and Literary Studies, 7 (5), pp.147-156, 2016.

[34] Abbas, B.; Ahmadreza, J.; Masoud, H. The beneficial impacts of applying formative assessment on Iranian university students' anxiety reduction and listening efficacys. International Journal of Languages' Education and Teaching, 5 (2), p. 1-11, 2017.

[35] Rahimi, M.; Soleymani, E. The impact of mobile learning on listening anxiety and listening comprehension. English Language Teaching, 8(10), 152-161, 2015. doi:10.5539/elt.v8n10p152.

[36] Valizadeh, M. R.; Alavinia, P. Listening comprehension performance viewed in the light of emotional intelligence and foreign language listening anxiety. English Language Teaching, 6 (12), 11-26, 2013.
[37] Serraj, S.; Noordin, N. Relationship among 1ranian efl students' foreign language anxiety, foreign language listening anxiety and their listening comprehension. English Language Teaching; 6 (5), 1-12, 2013.

[38] Kim, J.H. Foreign language listening anxiety: a study of Korean students learning English. (Unpublished Doctoral Dissertation), University of Texas, Austin, 2000.

[39] Melanlığlu, D. Impacts of authentic listening tasks upon listening anxiety and listening comprehension. Educational Research and Reviews, 8(14), pp. 1177-1185, 2013. DOI: 10.5897/ERR2013.1506.

[40] Arslan, A. Investigation of secondary school students' listening anxiety and academic self-efficacy beliefs in terms of various variables. International e-Journal of Educational Studies (IEJES), 1 (1), 12-31, 2017

[41] K1lınç, K. Effect of active learning techniques on 4th grade students' listening comprehension skills and attitudes towards listening. (Unpublished master's thesis).Adnan Menderes University, Aydın, 2015.

[42] Harmankaya, Ö. The effect of metacognitive strategies education on the listening comprehension skills, the attitudes towards listening and listening anxiety on secondary school students. (Unpublished master's thesis), Kırıkkale University, Turkey, 2016.

[43] Tekbıyık, A. İlişkisel araştırma yöntemi. M.Metin (Ed.) In Kuramdan Uygulamaya Eğitimde Bilimsel Araștırma Yöntemleri (pp.99-114). Ankara: Pegem A Publishing, 2015 .

[44] Özdamar, K. Paket programlar ile istatistiksel veri analizi 1-2. Eskişehir: Kaan Kitabevi, 2004.

[45] Çokluk, Ö.; Şekercioğlu, G. and Büyüköztürk, Ş. Sosyal bilimler için çok değişkenli istatistik spss ve lisrel uygulamalar1.Ankara: Pegem A Publishing, 2010.

[46] Uçgun, D. A research on reading and listening anxieties of secondary school students. Uluslararası Türkçe Edebiyat Kültür Eğitim Dergisi, 5(4), 1958-1970, 2016.

[47] Zhai, L. L. Influence of anxiety on english listening comprehension: An investigation based on the freshmen of English majors. Studies in Literature and Language, 11(6), 40-47, 2015

[48] Golchi, M. M., Listening anxiety and its relationship with listening strategy use and listening comprehension among Iranian IELTS learners. International Journal of English Linguistics, 2 (4), 2012.

[49] Halat, S.; Özbay, M. The examination of listening anxiety level of the students who learn Turkish as a foreign language. Universal Journal of Educational Research 6 (1), 1-10, 2018

[50] Otair, I., Abd Aziz, N. H. Exploring the causes of listening comprehension anxiety from efl saudi learners' perspectives: a pilot study. Advances in Language and Literary Studies, 8(4):79-84, 2017.

[51] Bayat, A.; Jamshidipour, A; and Hashemi, M. The beneficial impacts of applying formative assessment on iranian university students' anxiety reduction and listening efficacy. International Journal of Languages' Education and Teaching, 5 (2), p. 1-11, 2017. 
[52] Vogely, A. J. Listening comprehension anxiety: student's reported sources and solutions. Foreign Language Annals. 31 (1). 67-80, 1998

[53] Yang, J. The relationship between anxiety and listening comprehension in English learning. Foreign Language Research, (2), 2000

[54] Christenberry, B. Listening comprehension in the foreign language classroom, 2003. Retrieved from http:/Langlab.Uta.Edu/German/Lana.Rings/Fall01 gradstud ents/2001 paperchristenberry.Html
[55] MacIntyre, P. D.; Gardner, R. C. The measurement of anxiety and applications to second language learning: an annotated bibliography. University of Western Ontario, London. Dept. of Psychology, 1989.

[56] Funk, H. D. ; Funk, G. Guidelines for developing listening skills. The Reading Teacher, 42(9), pp. 660-663, 1989.

[57] Hyslop, N.; Tone, B. Listening: are we teaching it, and if so, how?. ERIC Digest Number 3.ERIC Publications; ERIC Digests in Full Text, 1988. 